\title{
INDIAN IT FIRMS CREATING MANAGEMENT CODES FOR FOREIGN EXCHANGE RISK
}

\author{
Dr. Nitin Shankar \\ Assistant Professor \\ Amity Business School, Amity University, Uttar Pradesh, Lucknow Campus, India \\ E-mail: nitinshankar19@gmail.com \\ Dr. Fatima Beena \\ Associate Professor \\ American College of Dubai, United Arab Emirates \\ E-mail: fatimabeena@gmail.com
}

\begin{abstract}
Purpose: India has been a preferred I.T. service sourcing nation globally and has been registering high growth. India has a significant pie of the global sourcing market, accounting for nearly $55 \%$ share. It covers significant global through its more than one thousand centres spread across continents. With a year-on-year growth of 6.1\%, India's I.T. and ITES industry will increase to the U.S. $\$ 350$ million by 2025. The extensive expanse of geographical coverage also translates into foreign exchange risk; hence foreign exchange risk management becomes an important strategy. The current study attempts to assess the impact of foreign exchange risk management on the Indian sector over 2007-2017; the period includes the 2008 financial crisis taken up in the current study.

Design/Methodology/ Approach: We analyzed the Indian I.T. companies listed on the BSE Ltd on their exposure, approach, and management towards foreign exchange risk. We investigated their annual reports from 2007 -2017 to understand their exposure and the adopted external foreign exchange risk management techniques. We further assessed the impact of these foreign exchange risk management techniques on the firm's value.

Findings: The impact of foreign exchange risk management was significant on small-cap I.T. companies for the study period. Though for the during the 2008 crisis term, it was found to be insignificant.

Practical/Implications: Foreign exchange risk management is crucial for Indian I.T. companies indulging in cross-border trade. The current study incorporates external methods of managing foreign exchange risk management; hence even if the impact were found to be insignificant for Mid Cap and some Large-cap companies, they would be practicing internal hedging methods, which puts a strong case tapping trillion-dollar business through a fully functional competitive International Financial Centre.

Originality/Value: Our paper contributes to the literature on Foreign exchange risk management by Indian I.T. companies, which contributes handsomely to India's GDP and Foreign exchange reserve.
\end{abstract}

Keywords: Foreign Exchange Risk Management, I.T., BSE.

JEL Classification Codes: F31, G32. 


\section{INTRODUCTION}

The objective of this current study will be to investigate foreign exchange exposure of Indian I.T. (Information Technology) Sector Companies, its measurement, and the steps taken to manage it. In particular, the paper would focus on measuring foreign exchange exposure of Indian of pharmaceutical Sector, External Control techniques to Manage Foreign Exchange Risk \& Impact of the Internal Control techniques to manage Foreign Exchange Risk. Risk exists whenever real outcomes deviate from the desired outcomes (Butler, 2002). Hence, the present study's risk is the possible event where outcomes are uncertain, leading to losses for the corporation involved. (Jorion, 2007) Business and Risk are not unknown to each other. Risk has been defined in various ways.

The uncertainty in the value of an asset, equity, or earnings due to unfavourable movement in the exchange rate is known as risk. As per Dun \& Bradstreet, Risk is defined as any possible event that can hinder the corporation's current and future reading.

Foreign exchange risk is also one of the multiple risks faced by the companies; however, for companies exposed to cross border trading, i.e. foreign currency, it becomes one of the critical factors affecting the firm's performance. The amount of trade in which firms engage in cross-border trade is exposure, and the volatility related to foreign exchange is a risk. Hence exposure and risk both are pretty different concepts (Levi, 2009).

It becomes an essential block in the firm's financial management if its objective is to minimize losses or maximize gains. With the current government's initiatives to increase crossborder trade through various initiatives like 'Make in India' to boost our economy, the integration of our economy with that of the world will become more intense and increase our firm's exposure multi-fold.

The amount of trade in which firms engage in cross-border trade is exposure, and the volatility related to foreign exchange is a risk. Hence exposure and risk both are pretty different concepts (Levi, 2009).

Pramborg (2005), Firmwide risk management is a popular term representing a combined and harmonized risk management outlook. Other expressions utilized to explain this combined and coordinated risk management are intercontinental risk management, strategic risk management, and enterprise risk management. The exchange risk exposure on both short and long term on a global basis is addressed by Firmwide risk management.

Muller and Verschoor (2006), from the survey of Nine hundred thirty-five U.S firms, twenty-nine percent of firms significantly impacted the foreign exchange currency movement/ fluctuations between 1990 and 2001.

Meier (2000), Firmwide risk management is one of the most widely used out of a group of synonyms that describe a broad and comprehensive view of managing risk across the firm. Other terms used to describe this type of coordinated risk management are enterprise risk management, global risk management, and strategic risk management. Firmwide risk management addresses exposures globally in that it considers all parts of the firm and tries to cope with both short-term and long-term exposures. For example, The Tower Group uses the term enterprise risk management. It defines it as "the process of managing the risk faced by an institution on a global, institution-wide basis."

Marshall (2000), a high proportion of U.K. respondents ranked foreign exchange risk management as significantly essential or most important, which is expected as the U.K. MNCs rely on a high degree of overseas business. One U.K. respondent explained that foreign exchange risk "impacts directly on the creation of shareholder value and competitive position'". However, 
this view does not seem to be shared in the USA as $45 \%$ of USA respondents report that foreign exchange risk management is marginally essential or least important. One USA respondent explained that "foreign exchange risk management is another attribute of doing business globally. It is one of the many items necessary to do business but is no more a burden than another item'.

It is a pearl of market wisdom that a firm's cash flow and valuation are affected by exchange rate movements, i.e. firms are exposed to foreign exchange exposure. Tracking foreign exchange exposure and devising its management strategies has garnered considerable attention, resulting in much research. For firms operating out of bustling economies like India, foreign exchange risk management becomes imperative

Gendreau (1994) finds it difficult and unconvincing that the weak results imply that exchange rate changes do not affect exporters' stock returns.

Bartov and Bodnar (1994) attribute the observed insignificant relationship between exchange-rate changes and stock returns to potential problems associated with the previous studies' sample selection procedure or mispricing caused by investors' errors in estimating this linkage.

Jorion (1990) finds that dollar depreciation exposure is positively related to the ratio of a firm's foreign sales to total sales.

However, these studies were based on an economy whose exchange rate is very stable. So it has called for more to study this phenomenon in the Indian context. The study takes on the Indian I.T. sector as its testing ground. Being a sector that developed and flourished on business from developed countries and bought foreign exchange in tonnes for the country, this is a perfect sector to undertake this study.

The exposure we are trying to measure is transaction risk which can be mitigated at a firm level, unlike economic exposure. Rodriguez (1974) states that proponents of the transaction exposure definition argue that a foreign operation is a long-term proposition. The only relevant exchange risks are those involved in short-term fluctuations in the host country's currency and other currencies.

Al-Momani \& Gharaibeh (2008), transaction exposure is related to the risk that arises from day-to-day transactions dealt with foreign currencies subject to volatility in value against the local currency.

External techniques are used by both exporters and importers as well as by multinational companies. The costs of the external exposure management methods are fixed and predetermined. The main external exposure management techniques are forward exchange contracts, short-term borrowing, discounting, forfeiting \& government exchange risk guarantees.

Dufey \& Srinivasulu (1983), Hedging can be accomplished either by forwarding contracts or by foreign currency borrowing and lending. The former is known as a forward market hedge and the latter as a money market hedge. Hence, obstacles to individuals in foreign money markets are also, in essence, obstacles to investor hedging. In many foreign money markets, nonresidents are denied access to local borrowing facilities or face discriminatory taxes.

Joseph (2000), a firm's degree of internationalization can affect the extent to which it uses hedging techniques (Mathur, 1985). Since firms appear to initially use internal techniques to hedge exposure (Hakkarainen et al., 1998), a positive relationship is expected between the measures of internationalization and the degree of utilization of internal techniques. In contrast, a negative relationship is expected between the rate of utilization of external techniques and the 
internationalization measures since the greater use of internal techniques implies less use of external techniques.

Joseph (2000), in general, external techniques appear to play a much more important role in hedging decisions than internal techniques. As the firms are large, scale economies in the use of external techniques and the availability of skilled treasury personnel may contribute to their greater use.

Carter, Pantzalis, and Simkins (2001), the use of currency forwards and other derivatives, decrease the firm's foreign-exchange exposure. Neither foreign-exchange options nor swaps appear to be associated with a reduction, or an increase, in exposure (In context to U.S. Multinational Corporations).

El-Masry (2006), large-sized firms are more likely to use derivatives because of the economies-to-scale argument for derivative use. Large firms are better able to bear the fixed cost of derivatives uses compared to small firms.

El-Masry (2006), it is interesting in knowing, if a firm uses derivatives for hedging, the most important reasons for using derivatives for hedging purposes. Four reasons for hedging are identified, and firms are asked to indicate the importance of these aspects. It was found that the most important reason for using hedging with derivatives is to manage the volatility in cash flows at $37 \%$ of the responding firms. The firm's market value is considered the second most important reason for using derivatives for hedging purposes, with $29 \%$ of the responding firms. This is followed by managing the volatility in accounting earnings at $25 \%$ and managing balance sheet accounts or ratios at $19 \%$.

Baranauskas, Jonuška, and Samėnaitė (2003), the main reason why forwards preferred options was that it costs less to use forwards. The majority of derivative users claimed that they are not willing to pay option premiums.

Rupeika-Apoga (2005), recently, most firms have adopted a more comprehensive approach to foreign exchange risk management, sometimes motivated by poor results of active foreign exchange management

\section{RESEARCH METHODOLOGY}

Researchers believe that foreign exchange risk management is essential for the firms exposed to cross-border trade, as it may directly impact the firm's performance and profitability. Particularly in India, the research in this aspect is little, so the researcher wants to throw light on the exchange risk management's effectiveness.

Thus, the present study used annual reports of listed companies across five sectors as The Companies Act, 2013 made it compulsory to disclose foreign Exchange Earnings/ Outgo and their Risk Management Policy. Further authenticity of the data made the study more robust. The firm's stock return data was taken from the stock exchange itself, i.e. BSE Ltd. Thus, the present study quantitative method is better.

\section{Validity and Reliability}

The present study data has been from the firm's annual reports taken from its official website and their returns on the stock exchange from BSE Ltd. The data was analyzed carefully with valid tools to ensure the present study's reliability. The present study period is for 2007-2017, so the results will be changing if the year or period changes. 


\section{Data Collection Method}

The current study was being based on six listed Indian I.T. companies; two each from Large Cap, Mid Cap \& Small Cap will be selected from the stock exchange (BSE). Risk Calculation through a model developed based on stock price and comparing it with base year price.

The present study is done over ten years, from 2007 to 2017 , to reflect the economic cycle in the findings. The periods also encompass one of the most turbulent times from 2007 to 2010, thus making study more enjoyable.

\section{Sources of Data}

Data forms the bedrock and basis for any relevant and authentic research. The present study, in its endeavour to FERM policies and their impact on Indian I.T. firm's secondary data sources were utilized.

Secondary data was mined from the company's authentic sources, Bombay Stock Exchange Ltd. (2018). (BSE Ltd.), Securities and Exchange Board of India (SEBI), Reserve Bank of India (RBI), World Economic Forum (WEF), World Trade Organisation.

\section{Tools \& Techniques}

Regression-based impact analysis. The study will be structured in two steps:

I Step: To study the foreign exchange exposure of Indian non-financial companies by scrutinising their financial statements and Annual Reports.

II Step: Once the Risk has been established, we try to determine the methods/techniques adopted by the Indian non-financial companies for foreign exchange risk management.

\section{OBJECTIVE OF THE STUDY}

The main objective of this study is to investigate the relationship between foreign currency risk and international business involvement, legal structure, firm size, sector, and management practices in the Indian environment.

The impact of firm-specific characteristics on the value of Indian IT companies will also be investigated by examining the level of foreign sales hedging, ROA, C.R., ERR

\section{PROBLEM}

There is a necessity to study the risk management methods adopted by the Indian I.T. companies to cover their exposure and its effectiveness to achieve the same in the absence of specialized financial services.

(Shapiro, 1975; Hodder, 1982; Levi, 2009; Bodnar \& Marston, 2002), whether a firm operates in the domestic or global market, it is affected by the exchange rate movement. Further, it is a standard theoretical view that exchange rate movements are one of the reasons for macroeconomic uncertainty

\section{MODEL}

The study evaluates the impact of foreign exchange on the firm value; it uses regression impact analysis. To make the model more comprehensive, three more independent variables were included in the model.

$$
Y=a+b_{1} X_{1}+b_{2} X_{2}+b_{3} X_{3}+b_{4} X_{4}
$$


Y representing the firm's value and the independent variable is hedge foreign exposure, Current ratio, Return on assets ratio, Earnings Return Ratio.

Anticipating the impact on a firm's value due to fluctuations in exchange rates has been a challenge for firms operating on a global scale. The risk management tools and techniques' effectiveness becomes the next challenge as different markets may demand different exchange risk management methods.

The present study has two primary areas of focus and inquiry the value of a firm and exchange risk exposure.

$$
Y(\text { Value of the firm })=a+b 1 \times 1(H F E)+b 2 \times 2(R O A)+b 3 \times 3(E R R)+b 4 \times 4(C R)
$$
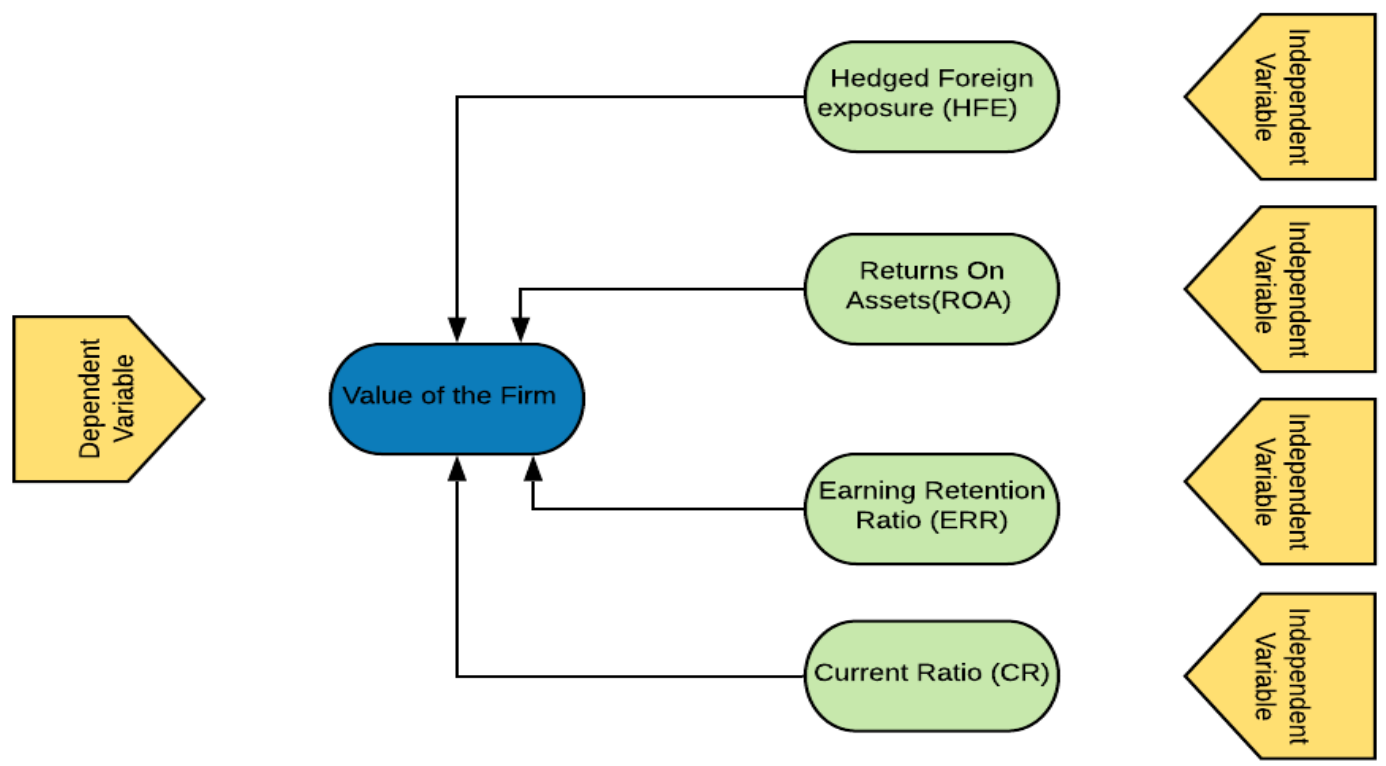

Figure 1. Conceptual Framework

\section{HYPOTHESIS}

Ho1. There is no impact of tools techniques used to manage foreign exchange risk Indian nonfinancial companies.

Table 1. IT TCS Co-efficient

\section{DATA ANALYSIS}

\begin{tabular}{|c|c|c|c|c|c|c|}
\hline \multicolumn{7}{|c|}{ Coefficients } \\
\hline \multirow{2}{*}{ Model } & \multicolumn{2}{|c|}{$\begin{array}{c}\text { Unstandardized } \\
\text { Coefficients }\end{array}$} & $\begin{array}{c}\text { Standardized } \\
\text { Coefficients }\end{array}$ & \multirow{2}{*}{ t } & \multirow{2}{*}{ Sig. } \\
\cline { 3 - 5 } \multicolumn{2}{|c|}{} & B & Std. Error & Beta & & \\
\hline \multirow{2}{*}{1} & (Constant) & 253193.569 & 241486.511 & & 1.048 & 0.335 \\
\cline { 3 - 7 } & HCE_TCS & 1.51 & 0.568 & 0.648 & 2.657 & 0.038 \\
\hline
\end{tabular}




\begin{tabular}{|c|c|c|c|c|c|c|}
\multicolumn{1}{|c}{} & ROA_TCS & 485.766 & 711.228 & 0.185 & 0.683 & 0.52 \\
\cline { 2 - 7 } & CR_TCS & 68187.365 & 176674.561 & 0.143 & 0.386 & 0.713 \\
\cline { 2 - 7 } & ERR_CS & -3136.109 & 2560.868 & -0.212 & -1.225 & 0.267 \\
\hline \multirow{4}{*}{2} & (Constant) & 330900.813 & 124965.134 & & 2.648 & 0.033 \\
\cline { 2 - 7 } & HCE_TCS & 1.684 & 0.326 & 0.723 & 5.17 & 0.001 \\
\cline { 2 - 7 } & ROA_TCS & 710.037 & 384.363 & 0.271 & 1.847 & 0.107 \\
\cline { 2 - 7 } & ERR_CS & -2502.675 & 1842.435 & -0.169 & -1.358 & 0.217 \\
\hline \multirow{3}{*}{3} & (Constant) & 172830.561 & 47892.19 & & 3.609 & 0.007 \\
\cline { 2 - 7 } & HCE_TCS & 1.668 & 0.342 & 0.716 & 4.872 & 0.001 \\
\cline { 2 - 7 } & ROA_TCS & 867.248 & 385.398 & 0.331 & 2.25 & 0.055 \\
\hline
\end{tabular}

Source: Above Table is Compiled by the scholar

Table 2. I.T. Infosys Co-efficient

\begin{tabular}{|c|c|c|c|c|c|c|}
\hline \multicolumn{7}{|c|}{ Coefficients } \\
\hline & \multirow{2}{*}{ Model } & \multicolumn{2}{|c|}{$\begin{array}{l}\text { Unstandardized } \\
\text { Coefficients }\end{array}$} & \multirow{2}{*}{$\begin{array}{c}\begin{array}{c}\text { Standardized } \\
\text { Coefficients }\end{array} \\
\text { Beta } \\
\end{array}$} & \multirow[t]{2}{*}{$\mathbf{t}$} & \multirow[t]{2}{*}{ Sig. } \\
\hline & & $\mathbf{B}$ & Std. Error & & & \\
\hline & (Constant) & 1100142.737 & 190801.873 & & 5.766 & 0.001 \\
\hline & HCE_INFOSYS & -0.319 & 0.411 & -0.161 & $\begin{array}{c}- \\
0.777\end{array}$ & 0.467 \\
\hline \multirow[t]{2}{*}{1} & ROA_INFOSYS & -37685.422 & 7529.584 & -0.893 & $\begin{array}{c}- \\
5.005\end{array}$ & 0.002 \\
\hline & CR_INFOSYS & 22383.187 & 40557.228 & 0.121 & 0.552 & 0.601 \\
\hline & ERR_INFOSYS & 685.044 & 2584.716 & 0.052 & 0.265 & 0.8 \\
\hline \multirow{4}{*}{2} & (Constant) & 1099284.614 & 177653.663 & & 6.188 & 0 \\
\hline & HCE_INFOSYS & -0.371 & 0.337 & -0.187 & $\begin{array}{c}- \\
1.101\end{array}$ & 0.307 \\
\hline & ROA_INFOSYS & -36702.056 & 6101.35 & -0.869 & 6.015 & 0.001 \\
\hline & CR_INFOSYS & 29162.843 & 29308.391 & 0.158 & 0.995 & 0.353 \\
\hline \multirow{3}{*}{3} & (Constant) & 1216289.661 & 133085.264 & & 9.139 & 0 \\
\hline & HCE_INFOSYS & -0.192 & 0.285 & -0.097 & $\begin{array}{c}- \\
0.674\end{array}$ & 0.519 \\
\hline & ROA_INFOSYS & -37412.406 & 6055.687 & -0.886 & $\begin{array}{c}- \\
6.178\end{array}$ & 0 \\
\hline \multirow{2}{*}{4} & (Constant) & 1228294.241 & 127832.811 & & 9.609 & 0 \\
\hline & ROA_INFOSYS & -38925.188 & 5451.933 & -0.922 & -7.14 & 0 \\
\hline
\end{tabular}

Source: Above the table is compiled by the authors 
Table 3. IT Tata Elxsi Co-efficient

\begin{tabular}{|c|c|c|c|c|c|c|}
\hline \multicolumn{7}{|c|}{ Coefficients } \\
\hline \multirow{2}{*}{\multicolumn{2}{|c|}{ Model }} & \multicolumn{2}{|c|}{$\begin{array}{l}\text { Unstandardized } \\
\text { Coefficients }\end{array}$} & \multirow{3}{*}{$\begin{array}{c}\begin{array}{c}\text { Standardized } \\
\text { Coefficients }\end{array} \\
\text { Beta }\end{array}$} & \multirow{3}{*}{$\begin{array}{c}\mathbf{t} \\
-1.15 \\
\end{array}$} & \multirow{3}{*}{$\begin{array}{c}\text { Sig. } \\
0.294\end{array}$} \\
\hline & & \multirow{2}{*}{$\begin{array}{c}\text { B } \\
-3897.464\end{array}$} & \multirow{2}{*}{$\begin{array}{c}\begin{array}{c}\text { Std. } \\
\text { Error }\end{array} \\
3387.637\end{array}$} & & & \\
\hline \multirow{5}{*}{1} & (Constant) & & & & & \\
\hline & HCE_TELX & 0.751 & 0.833 & 0.239 & 0.902 & 0.402 \\
\hline & ROA_TELX & -71.765 & 102.342 & -0.231 & -0.701 & 0.509 \\
\hline & CR_TELX & 6587.028 & 2850.181 & 0.892 & 2.311 & 0.06 \\
\hline & ERR_TELX & -27.757 & 69.564 & -0.158 & -0.399 & 0.704 \\
\hline \multirow{4}{*}{2} & (Constant) & -4037.79 & 3160.513 & & -1.278 & 0.242 \\
\hline & HCE_TELX & 0.727 & 0.779 & 0.231 & 0.933 & 0.382 \\
\hline & ROA_TELX & -84.794 & 90.982 & -0.273 & -0.932 & 0.382 \\
\hline & CR_TELX & 5924.369 & 2172.788 & 0.802 & 2.727 & 0.029 \\
\hline \multirow{2}{*}{3} & (Constant) & -3946.699 & 3132.949 & & -1.26 & 0.243 \\
\hline & HCE_TELX & 0.798 & 0.769 & 0.254 & 1.038 & 0.33 \\
\hline
\end{tabular}

Source: Above Table is compiled by the authors

Table 4. I.T. Mind tree Co-efficient

\begin{tabular}{|c|c|c|c|c|c|c|}
\hline \multicolumn{7}{|c|}{ Coefficients } \\
\hline & \multirow{2}{*}{ Model } & \multicolumn{2}{|c|}{$\begin{array}{c}\text { Unstandardized } \\
\text { Coefficients }\end{array}$} & \multirow{3}{*}{$\begin{array}{c}\begin{array}{c}\text { Standardized } \\
\text { Coefficients }\end{array} \\
\text { Beta } \\
\end{array}$} & \multirow{2}{*}{$\mathbf{t}$} & \multirow{2}{*}{ Sig. } \\
\hline & & B & Std. Error & & & \\
\hline \multirow{5}{*}{1} & (Constant) & -2959.707 & 3253.533 & & -0.91 & 0.398 \\
\hline & HCE_MTREE & 0.495 & 0.515 & 0.305 & 0.963 & 0.373 \\
\hline & ROA_MTREE & 8.085 & 56.83 & 0.034 & 0.142 & 0.892 \\
\hline & CR_MTREE & -568.669 & 415.285 & -0.304 & -1.369 & 0.22 \\
\hline & ERR_MTREE & 63.456 & 37.999 & 0.462 & 1.67 & 0.146 \\
\hline \multirow{4}{*}{2} & (Constant) & -2938.613 & 3014.128 & & -0.975 & 0.362 \\
\hline & HCE_MTREE & 0.455 & 0.399 & 0.281 & 1.14 & 0.292 \\
\hline & CR_MTREE & -558.146 & 378.969 & -0.299 & -1.473 & 0.184 \\
\hline & ERR_MTREE & 65.147 & 33.471 & 0.475 & 1.946 & 0.093 \\
\hline \multirow{3}{*}{3} & (Constant) & -3975.841 & 2927.021 & & -1.358 & 0.211 \\
\hline & CR_MTREE & -666.867 & 373.598 & -0.357 & -1.785 & 0.112 \\
\hline & ERR_MTREE & 87.797 & 27.441 & 0.64 & 3.199 & 0.013 \\
\hline \multirow{2}{*}{4} & (Constant) & -7572.36 & 2367.008 & & -3.199 & 0.011 \\
\hline & ERR_MTREE & 110.707 & 27.041 & 0.807 & 4.094 & 0.003 \\
\hline
\end{tabular}

Source: Above Table is compiled by the authors 
Table 5. I.T. Hexaware Co-efficient

\begin{tabular}{|c|c|c|c|c|c|c|}
\hline \multicolumn{7}{|c|}{ Coefficients } \\
\hline & \multirow{2}{*}{ Model } & \multicolumn{2}{|c|}{$\begin{array}{l}\text { Unstandardized } \\
\text { Coefficients }\end{array}$} & \multirow{3}{*}{$\begin{array}{c}\begin{array}{c}\text { Standardized } \\
\text { Coefficients }\end{array} \\
\text { Beta }\end{array}$} & \multirow{2}{*}{$\mathbf{t}$} & \multirow{2}{*}{ Sig. } \\
\hline & & B & $\begin{array}{c}\text { Std. } \\
\text { Error }\end{array}$ & & & \\
\hline \multirow{5}{*}{1} & (Constant) & 140.822 & 2794.133 & & 0.05 & 0.961 \\
\hline & HCE_HEXA & 5.572 & 1.155 & 0.949 & 4.825 & 0.003 \\
\hline & ROA_HEXA & 39.618 & 110.255 & 0.087 & 0.359 & 0.732 \\
\hline & CR_HEXA & -606.528 & 917.223 & -0.077 & -0.661 & 0.533 \\
\hline & ERR_HEXA & 4.636 & 13.176 & 0.065 & 0.352 & 0.737 \\
\hline \multirow{4}{*}{2} & (Constant) & 860.486 & 1780.52 & & 0.483 & 0.644 \\
\hline & HCE_HEXA & 5.545 & 1.078 & 0.945 & 5.146 & 0.001 \\
\hline & ROA_HEXA & 18.176 & 85.942 & 0.04 & 0.211 & 0.839 \\
\hline & CR_HEXA & -643.382 & 852.288 & -0.081 & -0.755 & 0.475 \\
\hline \multirow{3}{*}{3} & (Constant) & 761.058 & 1611.544 & & 0.472 & 0.649 \\
\hline & HCE_HEXA & 5.733 & 0.575 & 0.977 & 9.967 & 0 \\
\hline & CR_HEXA & -599.698 & 775.943 & -0.076 & -0.773 & 0.462 \\
\hline \multirow{2}{*}{4} & (Constant) & -250.501 & 918.936 & & -0.273 & 0.791 \\
\hline & HCE_HEXA & 5.635 & 0.548 & 0.96 & 10.277 & 0 \\
\hline
\end{tabular}

Source: Above the table is compiled by the authors

Table 6. IT NIIT Co-efficient

\begin{tabular}{|c|c|c|c|c|c|c|}
\hline \multicolumn{7}{|c|}{$\begin{array}{r}\text { Coefficients } \\
\end{array}$} \\
\hline \multirow{2}{*}{\multicolumn{2}{|c|}{ Model }} & \multicolumn{2}{|c|}{$\begin{array}{c}\text { Unstandardized } \\
\text { Coefficients }\end{array}$} & \multirow{3}{*}{$\begin{array}{c}\begin{array}{c}\text { Standardized } \\
\text { Coefficients }\end{array} \\
\text { Beta }\end{array}$} & \multirow{2}{*}{$\mathbf{t}$} & \multirow{2}{*}{ Sig. } \\
\hline & & B & $\begin{array}{c}\text { Std. } \\
\text { Error }\end{array}$ & & & \\
\hline \multirow{5}{*}{1} & (Constant) & 70.467 & 335.111 & & 0.21 & 0.84 \\
\hline & HCE_NIIT & 0.694 & 0.126 & 0.809 & 5.492 & 0.002 \\
\hline & ROA_NIIT & -17.104 & 18.807 & -0.173 & -0.909 & 0.398 \\
\hline & CR_NIIT & 164.55 & 74.513 & 0.167 & 2.208 & 0.069 \\
\hline & ERR_NIIT & 7.692 & 9.27 & 0.11 & 0.83 & 0.438 \\
\hline \multirow{4}{*}{2} & (Constant) & 281.831 & 212.824 & & 1.324 & 0.227 \\
\hline & HCE_NIIT & 0.766 & 0.09 & 0.893 & 8.548 & 0 \\
\hline & ROA_NIIT & -3.888 & 9.776 & -0.039 & -0.398 & 0.703 \\
\hline & CR_NIIT & 164.596 & 72.835 & 0.167 & 2.26 & 0.058 \\
\hline \multirow{3}{*}{3} & (Constant) & 213.713 & 119.52 & & 1.788 & 0.112 \\
\hline & HCE_NIIT & 0.793 & 0.055 & 0.925 & 14.482 & 0 \\
\hline & CR_NIIT & 152.687 & 62.806 & 0.155 & 2.431 & 0.041 \\
\hline
\end{tabular}

Source: Above the table is compiled by the authors 
Table 7. Results

\section{RESULT \& DISCUSSION}

\begin{tabular}{|c|c|c|c|c|c|c|c|c|c|c|c|c|c|}
\hline \multicolumn{14}{|c|}{ I.T. (INFORMATION TECHNOLOGY) } \\
\hline \multirow{3}{*}{$\begin{array}{c}\text { SECTOR } \\
\text { CAP } \\
\text { FIRM NAME }\end{array}$} & & \multicolumn{11}{|c|}{$\begin{array}{ll}\text { SECTOR } \\
\end{array}$} & \multirow[b]{3}{*}{ SIG } \\
\hline & & \multicolumn{3}{|c|}{ LARGE } & \multicolumn{4}{|c|}{ MID } & \multicolumn{4}{|c|}{ SMALL } & \\
\hline & & TCS & SIG & Infosys & SIG & $\begin{array}{l}\text { Tata } \\
\text { elexi }\end{array}$ & SIG & $\begin{array}{c}\text { Mind } \\
\text { Tree }\end{array}$ & SIG & Hexa & SIG & NIIT & \\
\hline & $\mathbf{A}$ & & & & & & & & & & & & \\
\hline \multirow{11}{*}{$\begin{array}{c}\text { COEFFICIENT TABLE } \\
\text { Y }=\mathrm{A}+ \\
\text { B1X1+B2X2+B3X3+B4X4 }\end{array}$} & $\begin{array}{c}\text { intercept } \\
\alpha\end{array}$ & 253194 & & 1100142 & & 3897 & & -2960 & & 140.82 & & 70.5 & \\
\hline & B1, HCE & 1.51 & 0.0 & -0.319 & 0.5 & 0.75 & 0.4 & 0.495 & 0.4 & 5.572 & 0.0 & 0.69 & 0.0 \\
\hline & $\begin{array}{c}\mathbf{P} \\
\text { VALUE }\end{array}$ & & & & & & & & & & & & \\
\hline & & & & & & & & & & & & & \\
\hline & $\begin{array}{c}\text { B2, } \\
\text { ROA }\end{array}$ & 485.766 & 0.5 & -37685 & $\mathbf{0 . 0}$ & $\overline{71.8}$ & 0.5 & 8.085 & 0.9 & 39.618 & 0.7 & -17 & 0.4 \\
\hline & $\begin{array}{c}\mathbf{P} \\
\text { VALUE }\end{array}$ & & & & & & & & & & & & \\
\hline & B3, CR & 68187.4 & 0.7 & 22383 & 0.6 & 6587 & 0.1 & $\begin{array}{c}- \\
568.7\end{array}$ & 0.2 & -606.5 & 0.5 & 165 & 0.1 \\
\hline & $\begin{array}{c}\mathbf{P} \\
\text { VALUE }\end{array}$ & & & & & & & & & & & & \\
\hline & & & & & & & & & & & & & \\
\hline & B4, ERR & & & & & & & & & & & & \\
\hline & $\begin{array}{c}\text { P } \\
\text { VALUE }\end{array}$ & -3136.1 & 0.3 & 685 & 0.8 & 27.8 & 0.7 & 63.46 & 0.1 & 4.636 & 0.7 & 7.69 & 0.4 \\
\hline
\end{tabular}

Source: Author's compilation

The present study findings of the I.T. sector show a clear trend that (Slope) $\beta$, i.e. rate of return per unit hedged funds, of the small-cap firms, are significant.

Table 8. Hypothesis assessment summary

\begin{tabular}{|c|c|c|c|c|c|}
\hline OBJECTIVE & HYPOTHESIS & $\begin{array}{l}\text { SECTOR/ } \\
\text { COMPANY }\end{array}$ & $\begin{array}{c}\text { INDEPENDENT } \\
\text { VARIABLE }\end{array}$ & Significance & $\begin{array}{l}\text { Ho: Null Hypothesis } \\
\text { Accepted/ Rejected }\end{array}$ \\
\hline $\begin{array}{c}\text { To } \\
\text { study the } \\
\text { impact } \\
\text { analysis of } \\
\text { tools and } \\
\text { techniques } \\
\text { used to } \\
\text { manage }\end{array}$ & $\begin{array}{l}\mathrm{H}_{0}: \text { There is no } \\
\text { impact of tools } \\
\text { techniques used to } \\
\text { manage foreign } \\
\text { exchange risk } \\
\text { Indian non- } \\
\text { financial } \\
\text { companies. }\end{array}$ & IT/LARGE/TCS & HCE & Significant & Rejected \\
\hline
\end{tabular}




\begin{tabular}{|c|c|c|c|c|c|}
$\begin{array}{c}\text { foreign } \\
\text { exchange risk } \\
\text { Indian non- } \\
\text { financial } \\
\text { companies. }\end{array}$ & $\begin{array}{c}\mathbf{H}_{1} \text { : There is an } \\
\text { impact of tools } \\
\text { techniques used to } \\
\text { manage foreign } \\
\text { exchange risk } \\
\text { Indian non- } \\
\text { financial } \\
\text { companies. }\end{array}$ & IT/SMALL/HEXAWARE & HCE & Significant & Rejected \\
\cline { 2 - 6 } & IT/SMALL/NIIT & HCE & Significant & Rejected \\
\hline
\end{tabular}

\section{Financial Crisis times}

India has been a preferred I.T. service sourcing nation in the world and has been registering high growth. India has a significant pie of the global sourcing market, accounting for nearly $55 \%$ share. It covers significant global through its more than one thousand centres spread across continents. With a year-on-year growth of $6.1 \%$, India's I.T. and ITES industry will increase to the U.S. $\$ 350$ million by 2025 .

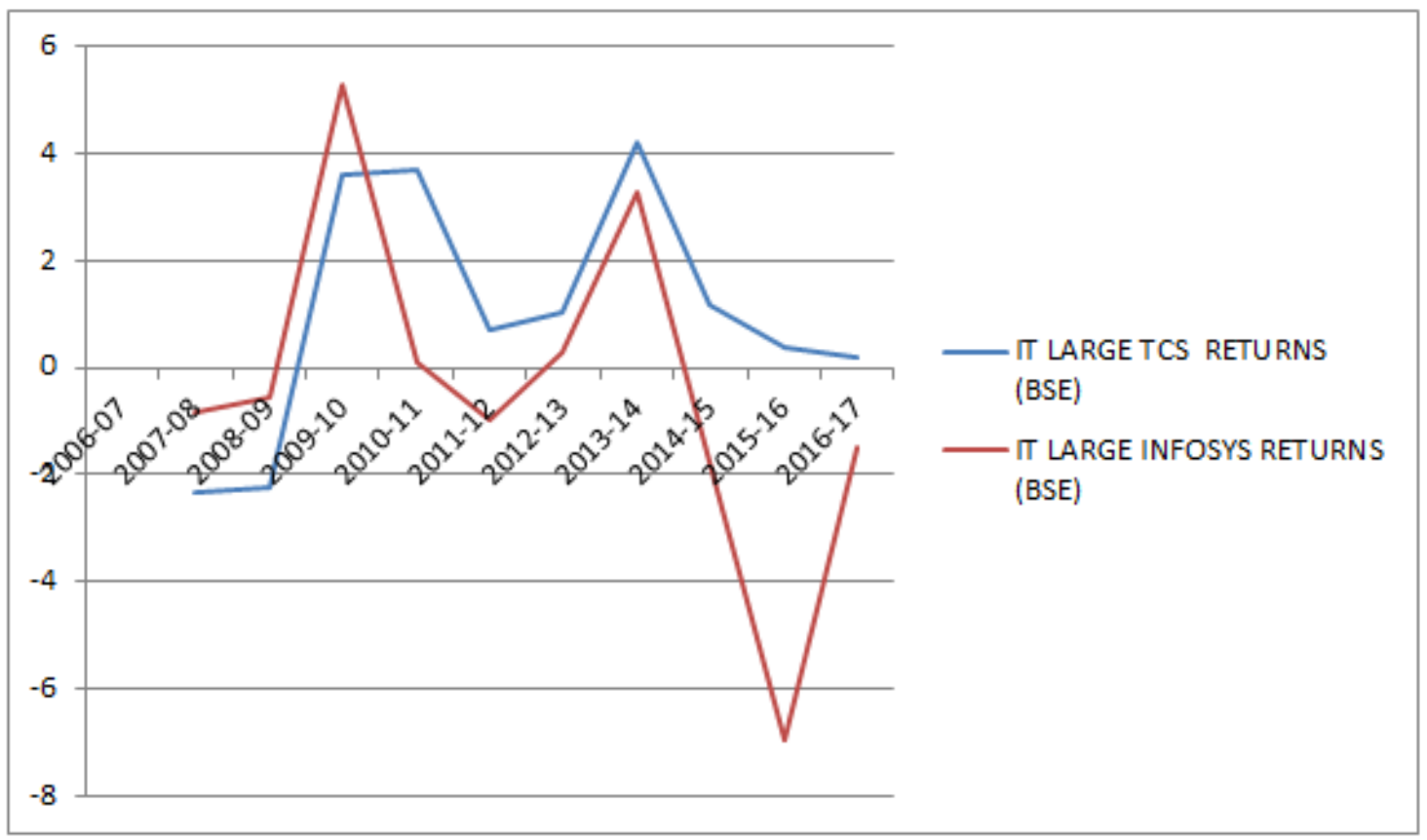

Figure 2. Stock Returns (large)

The above graph reflects a sluggish IT Large Cap movement of TCS and Infosys on BSE in the crisis years 2007-09 and only starts picking up at the inception of 2010.

$H_{0} \beta_{0}$, The Slope term in the regression of returns on hedged forex exposure, is statistically insignificant.

Ho for Large IT firms TCS and Infosys is significant at 5\% level with P Values 0.025 and 0.027 for 2007-2010. 
Though during the period of the present study, i.e. 2007-2017, The Ho only holds for TCS and not for Infosys

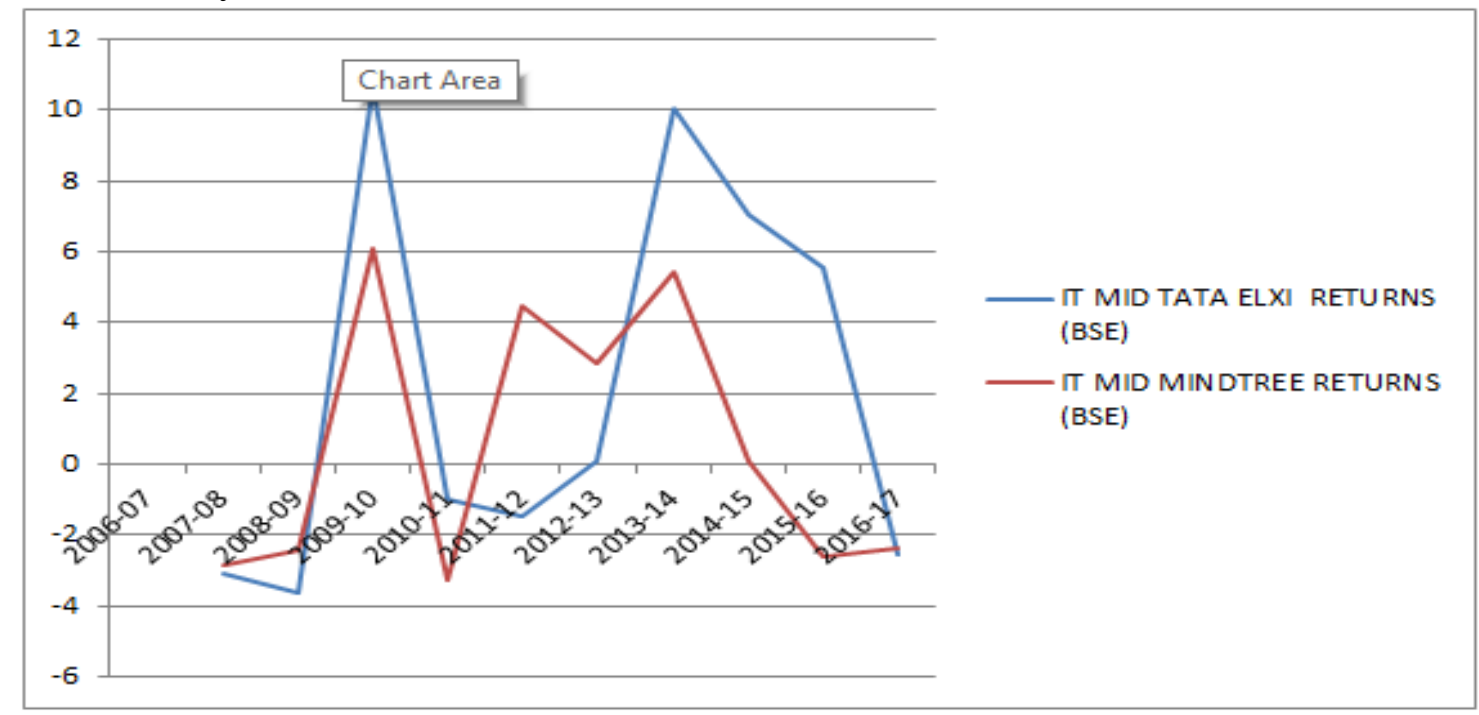

Figure 3. Stock Returns (mid)

The above graph clearly reflects the IT MID Cap stocks movement of Tata Elxsi and Mindtree on BSE in the crisis years 2007-09 and only starts looking up at the inception of 2010 and then dips in 2010 again.

$\mathrm{H}_{\mathrm{o}} \beta_{0}$, The Slope term in the regression of returns on hedged forex exposure, is statistically insignificant.

Ho for IT MID Cap companies Tata Elxsi and Mindtree is found to be is insignificant at 5\% level with P Values 0.428 and 0.73 for the period 2007-2010.

During the present study period, i.e. 2007-2017, The Ho is also insignificant for both Mid Cap firms.

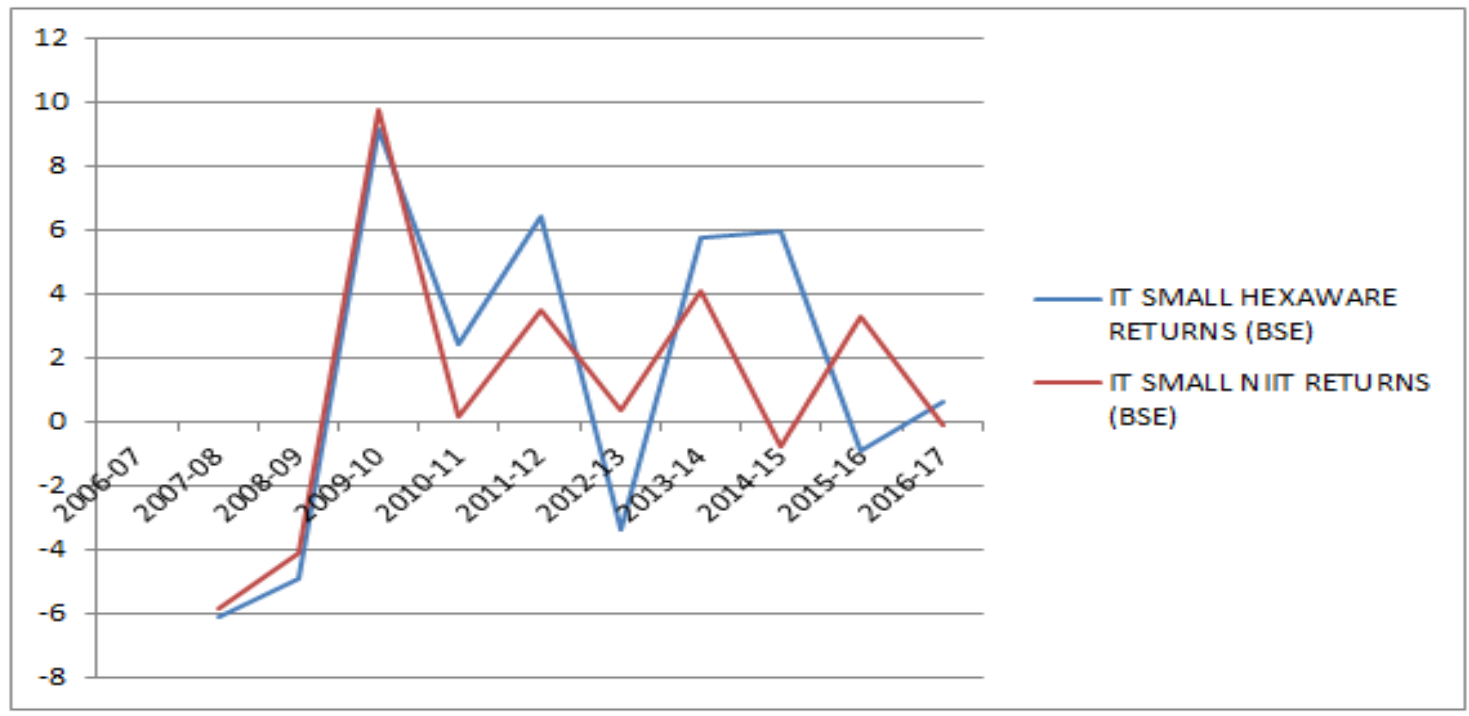

Figure 4. Stock Returns (small) 
The above graph reflects a very rocky stock's movement of Hexaware and NIIT on BSE in the crisis years 2007-09, with business picking up in 2009.

$\mathrm{H}_{\mathrm{o}} \beta_{0}$, The Slope term in the regression of returns on hedged forex exposure, is statistically insignificant.

Ho for IT Small Cap companies Hexaware significant at 5\% with P-value 0.046 and NIIT is found to be is insignificant at 5\% level with P Values 0.238 for the period 2007-2010.

During the present study period, i.e. 2007-2017, The Ho is significant for small-cap firms.

\section{CONCLUSION}

The study concludes foreign exchange management has a relationship with firms' stock performance on BSE; however, this impact varies with the size of the company in the Indian I.T. sector. The impact of foreign exchange risk management was significant for small-cap I.T. companies, Hexaware and NIIT, and large-cap companies, TCS. The current study undertakes only external hedging techniques as the same is available in the public domain. The firm also undertakes internal hedging practices like swapping, netting, etc. It also opens the opportunity to establish a sophisticated financial centre on the standard playing field as with other established international financial centres. The foreign exchange risk is imperative when a firm adopts an internationalization strategy to grow; hence its management also impacts its value, as found by the current study.

\section{REFERENCES}

Al-Momani, R., \& Gharaibeh, M. R. (2008). Foreign exchange risk management practices by Jordanian nonfinancial firms. Journal of Derivatives \& Hedge Funds, 14(3), 198-221.

Baranauskas, G., Jonuška, M., \& Samėnaitė, I. (2003). Foreign exchange risk management in Lithuanian companies: the use of currency derivatives. Organizaciju vadyba: sisteminiai tyrimai, (26), 57-75.

Bartov, E., \& Bodnar, G. M. (1994). Firm valuation, earnings expectations, and the exchange-rate exposure effect. The journal of Finance, 49(5), 1755-1785.

Bombay Stock Exchange Ltd. (2018). Markets-Historical Data-stocks. Retrieved fromhttps://www.bseindia.com/markets/equity/EQReports/StockPrcHistori.aspx?expand able $=7 \&$ flag $=0$

Bodnar, G. M., \& Marston, R. C. (2002). Exchange rate exposure: A simple model. In Global Risk Management: Financial, Operational, and Insurance Strategies. Emerald Group Publishing Limited.

Butler, K. C. (2002). Multinational Finance. New Delhi: Vikas Publishing House Pvt. Ltd.

Carter, D., Pantzalis, C., \& Simkins, B. J. (2001). Firmwide risk management of foreign exchange exposure by U.S. multinational corporations. Available at SSRN 255891. 
Dufey, G., \& Srinivasulu, S. L. (1984). The case for corporate management of foreign exchange risk. Financial Review, 19(3), 39-39.

El-Masry, A. A. (2006). The exchange rate exposure of U.K. nonfinancial companies: industry level analysis. Managerial Finance, 32(2), 115-136.

Gendreau, B. (1994). Comments on exchange rates, the macroeconomic environment, and the firm. Exchange Rates and Corporate Performance, 67-71.

Hakkarainen, A., Joseph, N., Kasanen, E., \& Puttonen, V. (1998). The foreign exchange exposure management practices of Finnish industrial firms. Journal of International Financial Management \& Accounting, 9(1), 34-57.

Hodder, I. (1982). Structural and Symbolic Archaeology. Cambridge University Press.

Jorion, P. (1990). The Exchange-Rate Exposure of U.S. Multinationals. Journal of Business, $63(3), 331-345$.

Jorion, P. (2007). Value at risk: the new benchmark for managing financial risk. The McGrawHill Companies, Inc..

Joseph, N. L. (2000). The choice of hedging techniques and the characteristics of U.K. industrial firms. Journal of Multinational Financial Management, 10(2), 161-184.

Levi, M. D. (2009). International Finance. Oxon: Routledge.

Marshall, A. P. (2000). Foreign exchange risk management in UK, USA and Asia Pacific multinational companies. Journal of Multinational Financial Management, 10(2), 185211.

Mathur, B. C. (1985). Administrative Reforms. Indian Journal of Public Administration, 31(3), 548-560. https://doi.org/10.1177/0019556119850308

Meier, R. L. (2000). Integrating enterprise-wide risk management concepts into industrial technology curricula. Journal of industrial technology, 16(4), 1-15.

Muller, A., \& Verschoor, W. F. (2006). Asymmetric foreign exchange risk exposure: Evidence from U.S. multinational firms. Journal of Empirical Finance, 13(4-5), 495-518.

Pramborg, B. (2005). Foreign exchange risk management by Swedish and Korean nonfinancial firms: A comparative survey. Pacific-Basin Finance Journal, 13(3), 343-366.

Rodriguez, R. M. (1974). Management of Foreign Exchange Risk in the U.S. Multinationals. Journal of Financial and Quantitative Analysis, 9(5), 849-857. 
Rupeika-Apoga, R. (2005). Nowadays Approach to Foreign Exchange Risk Management. Management of Organizations: Systematic Research, (35).

Shapiro, A. C. (1975). Exchange rate changes, inflation, and the value of the multinational corporation. The Journal of Finance, 30(2), 485-502.

\section{Copyrights}

Copyright for this article is retained by the author(s), with first publication rights granted to the journal. This is an open-access article distributed under the terms and conditions of the Creative Commons Attribution license (http://creativecommons.org/licenses/by/4.0/) 